\title{
Direct Immunoassay of Triiodothyronine in Human Serum
}

\author{
P. R. LARSEN \\ From the Division of Endocrinology and Metabolism, Department of Medicine, \\ University of Pittsburgh School of Medicine, Pittsburgh, Pennsylvania 15213
}

A B S T R A C T A sensitive and precise radioimmunoassay for the direct measurement of triiodothyronine $\left(T_{3}\right)$ in human serum has been designed using sodium salicylate to block $T_{3}-T B G$ binding. This assay is sufficiently sensitive to quantitate $T_{s}$ accurately in 50 $100 \mu \mathrm{l}$ of normal serum and to measure quantities as small as $12.5 \mathrm{pg}$ in $0.2 \mathrm{ml}$ of hypothyroid serum. The $T_{3}$ values observed in euthyroid subjects and in patients with various thyroid diseases are as follows: euthyroid (38) $1.10 \pm 0.25$ (SD) $\mathrm{ng} / \mathrm{ml}$, hypothyroid (25) 0.39 \pm 0.21 ( $\mathrm{sD}) \mathrm{ng} / \mathrm{ml}$, and hyperthyroid (24) $5.46 \pm 4.42$ (sD) $\mathrm{ng} / \mathrm{ml}$. The levels of $\mathrm{T}_{3}$ parallel the thyroxine ( $\left.\mathrm{T}_{4}\right)$ concentration in the sera of these subjects. In eight pregnant women at the time of delivery, $\mathrm{T}_{3}$ concentrations were in the upper normal range (mean $1.33 \mathrm{ng} / \mathrm{ml}$ ). The levels of $\mathrm{T}_{3}$ in cord serum obtained at the time of delivery of these patients (mean 0.53 $\mathrm{ng} / \mathrm{ml}$ ) are distinctly lower and close to the hypothyroid mean.

Administration of $10 \mathrm{U}$ of bovine thyroid-stimulating hormone (TSH) to euthyroid subjects causes a twofold increase in serum $T_{3}$ levels within $8 \mathrm{hr}$. At this time, the increase in serum $T$. concentration is only $41 \%$. In two subjects in whom thyroid secretion was acutely inhibited, one after pituitary surgery and another after thyroidectomy, the serum $T_{3}$ fell into the hypothyroid range within 1-2 days. Thus, serum $T_{3}$ concentrations appear to be a sensitive index of acute changes in thyroid hormone secretion and should prove to be a useful adjunct to both the clinical and physiological evaluation of thyroid function.

\section{INTRODUCTION}

Triiodothyronine $\left(T_{3}\right)^{1}$ was initially identified in human serum in 1952 by Gross and Pitt-Rivers (1).

\footnotetext{
Received for publication 1 November 1971 and in revised form 22 February 1972.

1 Abbreviations used in this paper: BSA, bovine serum albumin ; CDI, carbodiimide; DIT, diiodotyrosine; HSA, human serum albumin; MIT, monoiodytyrosine; $\mathrm{T}_{3}$, triiodothyronine; $T_{4}$, thyroxine; $T B G$, thyroxine-binding globulin; $\mathrm{TSH}$, thyroid-stimulating hormone.
}

It was soon recognized that this hormone was more potent than thyroxine $\left(T_{4}\right)$ and had a more rapid onset of action. However, because of the tedious methods required for its quantitation, evaluation of its role in human thyroid physiology and pathophysiology was not possible. In recent years, less cumbersome methods for quantitation of $\mathrm{T}_{3}$ in human serum have been developed $(2,3)$. The method described by Sterling and coworkers has allowed new insight into the importance of this hormone (3). It has been estimated that $T_{3}$, arising either via primary secretion or via $T_{4}$ deiodination, provides greater than $50 \%$ of the human thyroid hormone requirement (4). Although the availability of the Sterling method has added new impetus to the investigation of this hormone, careful evaluation of this technique in our laboratory and in others has suggested that it may overestimate the concentration of $\mathrm{T}_{3}$ in human serum (5-7). The primary cause of this artifact appears to be the unavoidable deiodination of $T_{4}$ to $T_{s}$ during the paper chromatographic separation of the two hormones after extraction from human serum. This separation was a necessary step due to the fact that thyroxine-binding globulin (TBG), used as the competitive binding protein, has a higher affinity for $T_{4}$ than for $T_{3}(8)$. Furthermore, relatively large quantities of serum were required for accurate assay of $T_{3}$ in normals and in hypothyroid patients. This limited its usefulness in physiologic studies.

Because of these difficulties, there was a need to develop an assay which could measure $T_{3}$ accurately in the presence of $T_{4}$ in a small volume of serum. To this end, a number of investigators have successfully induced the formation of specific anti- $T_{3}$ antibodies by immunization with various $\mathrm{T}_{3}$-protein conjugates or with thyroglobulin (9-13). While it was possible to develop antibodies with an extreme specificity for $T_{s}$ vs. $T_{4}$, the competition of the TBG present in human serum with the antibody for $\mathrm{T}_{3}$ appeared to be a further technical obstacle to the precise quantitation of the hormone in unextracted serum. This problem has been approached by the addition of various compounds (thyroxine [11], tetrachlorthyronine [12], diphenylhydantoin [13]) to the assay system to block $T_{3}-T B G$ binding. 
TABLE I

Procedure for Immunoassay of $T_{3}$ in Human Serum

\section{Solutions}

Blank solution: Glycine $(0.2 \mathrm{M})-\mathrm{Na}$ acetate $(0.13 \mathrm{M})$, BSA-20 $\mathrm{mg} / 100 \mathrm{ml}$, sodium salicylate- $10 \mathrm{mg} / \mathrm{ml}$.

$\begin{array}{ll}\text { Tracer solution: } & \text { Blank solution plus } T_{3}-126 I \text { approximately } 0.2 \mathrm{ng} / \mathrm{ml} \text {. } \\ \text { Antibody solution: } & \text { Rabbit anti- } T_{3} \text { antiserum diluted } 1 / 75,000 \text { in blank }\end{array}$ Antibody solution: Rabbit anti-1

Standards :

$0,0.025,0.050,0.10,0.15,0.20,0.30$, and $0.40 \mathrm{ng}$ of $T_{3}$ in $0.2 \mathrm{ml}$ of $T_{3}$-free human serum.

Scheme for Performing Assay

Volume $m l$

Tubes containing antiserum

Standard curve: appropriate standard in $T_{3}$-free serum Standard curve: antibody solution

Unknowns: 0.005-0.200 ml. of unknown serum made up to a total volume of $0.2 \mathrm{ml}$ with $\mathrm{T}$,-free serum

Unknowns: antibody solution

Blanks (tubes with no antiserum)

Standard curve: $\mathbf{T}_{2}$-free serum

Standard curve: blank solution

Unknowns: $0.005-0.200 \mathrm{ml}$ of unknown serum made up to a total volume of $0.2 \mathrm{ml}$ with $\mathrm{T}_{2}$-free serum (corresponds to volume of unknown serum assayed in the tubes containing antiserum)

Unknowns: blank solution
0.200

0.700

0.900 (Total)
All tubes incubated 2-5 days at $4^{\circ} \mathrm{C}$.

$0.100 \mathrm{ml}$ tracer solution added to all tubes.

Incubate $2-3$ days at $4^{\circ} \mathrm{C}$.

Count every 10 th tube.

Add $1 \mathrm{ml}$ charcoal-dextran solution, incubate $45 \mathrm{~min}$ in an ice bath

Centrifuge $15 \mathrm{~min}$ at $2000 \mathrm{rpm}$, decant supernate, and count $1 \mathrm{ml}$.

Calculations

Observed per cent bound $=\frac{\text { counts }^{125} \mathrm{I} / \mathrm{ml} \text { supernate } \times 2 \times 100}{\text { total initial counts } T_{3} 125 \mathrm{I} / \text { tube }}$

for both antibody and blank tubes

True per cent bound

observed per cent bound (antibody) - blank per cent bound $\times 100$ 100 - blank per cent bound

The data was then transposed by letting the per cent bound at $0 \mathrm{~T}_{3}$ concentration equal $100 \%$.

The quantity of $T_{3}$ in the unknown is determined by reference to the standard curve and expressed as $\mathrm{ng} \mathrm{T}_{3} / \mathrm{ml}$.

We have previously reported evidence that sodium salicylate inhibits binding of $\mathrm{T}_{3}$ and $\mathrm{T}_{4}$ to human TBG $(14-16)$. In a recent communication, we have also shown that this property of salicylates can be used to block the binding of $T_{3}$ to TBG during the immunoassay of $T_{3}$ in unextracted human serum. The drug did not interfere significantly with the binding of $T_{3}$ to the antibody (15). This report demonstrated that the use of salicylate in the assay allowed quantitative recovery of $\mathrm{T}_{3}$ from human serum by direct immunoassay.

The present communication extends these observations and presents results of the direct measurement of
$T_{3}$ in serum from normal subjects, from patients with thyroid disease, during pregnancy, and in cord serum.

\section{METHODS}

Preparation of antigen. Two methods were used for the coupling of $T_{3}$ to bovine and human serum albumin. The first was that of Goodfriend, Levine, and Fasman in which $\mathrm{Na}-3,5,3^{\prime}$ triiodothyronine, $10 \mathrm{mg}$ (plus $\left.\mathrm{T}_{\mathbf{z}^{-}}{ }^{205} \mathrm{I}\right)$, was coupled to $20 \mathrm{mg}$ of bovine serum albumin (BSA) using ethyl carbodiimide (17). After termination of the coupling reaction, $\mathrm{T}_{3^{-131}} \mathrm{I}$ was added to quantitate removal of unconjugated $T_{2}$ from the albumin- $T_{3}$ mixture during extensive dialysis ( $1 \mathrm{wk}$ against approximately 50 liters of $0.1 \mathrm{M}$ phosphate buffer 7.4 at room temperature).

At this time, $20 \%$ of the $\mathrm{T}_{\mathrm{r}^{-}}{ }^{121} \mathrm{I}$ still remained in the protein solution. The quantity of residual unbound $\mathrm{T}_{\mathrm{s}}{ }^{125} \mathrm{I}$ was then estimated. Using the original specific activity of the $\mathrm{T}_{3}{ }^{105} \mathrm{I}$ and the protein concentration, it was calculated that 1-2 moles of $T_{3}$ were covalently linked per mole albumin in the supernate of this suspension. However, since albumin- $T_{s}$ was not separated from unconjugated albumin, the quantity of $T_{3}$ conjugated per mole albumin could only be estimated as an average, since variable quantities of $T_{8} /$ mole of albumin may be present. The insoluble and soluble portions of this mixture were lyophilized together and reconstituted in isotonic saline at a concentration of $2 \mathrm{mg} / \mathrm{ml}$. Though obviously cloudy, this saline suspension was mixed with an equal quantity of complete Freud's adjuvant (Difco Laboratories, Detroit, Mich.) and $1 \mathrm{ml}(1 \mathrm{mg})$ injected in $0.1 \mathrm{ml}$ amounts into the toe pads of four New Zealand white rabbits (designated $\mathrm{A}, \mathrm{B}, \mathrm{C}, \mathrm{D})$. The second antigen, $\mathrm{T}_{3}$-human serum albumin (HSA), was prepared by the method of Oliver, Parker, Brasfield, and Parker, as modified by Gharib, Mayberry, and Ryan $(10,18)$. The four rabbits, A-D, received an additional injection of $1 \mathrm{mg}$ of this second antigen 3-4 wk after the injection of the first antigen and again 2 wk later. Antisera were harvested beginning 10 days after the second injection. Two of the initial four rabbits died $(\mathrm{B}, \mathrm{C})$. The two remaining rabbits $(\mathrm{A}, \mathrm{D})$ have produced antisera with a maximum titer of 1 to $100,000-150,000$ for use in the assay described below. Animals immunized with only the $\mathrm{T}_{\boldsymbol{\sigma}}-\mathrm{HSA}$ conjugate $(\mathrm{E}, \mathrm{F})$, produced antisera of equal affinity, but with usable titers of approximately $1 / 5000$ $1 / 10,000$. All of the studies to be reported were performed with antisera labeled A215-71 (rabbit A).

Immunoassay procedure. After extensive experimental evaluation, the immunoassay procedure described in Table I was adopted. The $T_{3^{-}}{ }^{225} \mathrm{I}$ was kindly donated by $J$. F. Jeffries of Abbott Laboratories, North Chicago, Ill. It had a high specific activity $(300-500 \mathrm{mCi} / \mathrm{mg})$. This allowed $5-10,000$ counts to be added with a $T_{3}$ concentration of less than 0.03 ng of tracer per assay tube.

$\mathrm{T}_{3}$-free human serum was prepared as follows: tracer $\mathrm{T}_{3-}$ ${ }^{205} \mathrm{I}$, approximately 10,000 counts $/ \mathrm{ml}$, was added to pooled human serum. Then, approximately $7.5 \mathrm{~g}$ of Norit A decolorizing pharmaceutical charcoal were added per $100 \mathrm{ml}$ of serum and mixed at $4^{\circ} \mathrm{C}$ for a period of at least $3 \mathrm{hr}$ (although 12-24-hr periods are usually used for convenience). The serum was then centrifuged for three successive $1 \mathrm{hr}$ periods at $25,000 \mathrm{~g}$ and the clear supernate was removed after each centrifugation. Comparison of quantities of $\mathrm{T}_{3^{-125}} \mathrm{I}$ before and after charcoal addition demonstrated that less than $1 \%$ of the original $\mathrm{T}_{3}{ }^{-255} \mathrm{I}$ remained in the solution. Protein concentration, osmolality, and TBG capacity (by reverse-flow electrophoresis [19]) were unchanged, although 
approximately $90 \%$ of the $\mathrm{T}_{4}$ present in the serum was also removed by this technique. Numerous control studies have shown that this serum behaves identically in the immunoassay with serum in which the $T_{4}$ concentration has been returned to normal amounts using specially purified $T_{4}$ (see below), and with sera of a patient with profound myxedema.

$T_{3}$ enrichment of the $T_{3}$-free serum to $4 \mathrm{ng} / \mathrm{ml}$ was carried out with $\mathrm{T}_{3}$ dissolved in $0.04 \mathrm{~m} \mathrm{NaOH}$. The gravimetric concentration of $T_{3}$ in the preparation was verified by its absorbance at $320 \mathrm{~m} \mu$ using the known molar extinction coefficient previously determined by Gemmill (20). The accuracy of the dilution of the final $T_{3}$ preparation to be added to serum was monitored by tracer $\mathrm{T}_{3}$. Standard serum containing $\mathrm{T}_{3}$ has been kept for up to 3 wk at $-20^{\circ} \mathrm{C}$ with no significant change in the displacement curve.

The charcoal-dextran solution, prepared as previously described, was diluted two parts charcoal-dextran to three parts glycine-acetate buffer immediately before addition to the assay tube (5). The solution was kept at $4^{\circ} \mathrm{C}$ until addition and was transferred from a beaker which was constantly stirred with a magnetic stirring bar. In practice, charcoal-dextran is added to the tubes in groups of 30 to 40 . This grouping is dictated by the requirement that there should be less than $4 \mathrm{~min}$ difference in the duration of exposure of the first and last tubes of the group to the charcoal-dextran. To ascertain that the per cent of $T_{3^{-}}{ }^{125} \mathrm{I}$ bound by the charcoal has not varied during the procedure, two antibody tubes containing no added $T_{3}$ are run with each group-one, the first, and the other the last tube to receive charcoal-dextran. The charcoal-dextran is added to each of the standard triplicates in different groups. Unknown samples and corresponding blanks are assayed in duplicate at two dilutions, also in different groups. All assays have been carried out in $16 \times 125 \mathrm{~mm}$ plastic test tubes obtained from Amersham-Searle Corp., Arlington Heights, Ill.

The per cent tracer bound in the blank (without antibody) in the $\mathrm{T}_{3}$-free serum $(0.2 \mathrm{ml})$ varied from 7.1 to 10.7 (mean $8.6 \%$ ) in 13 separate assays with a standard deviation of less than $1.0 \%$ within each assay. A "blank" which gives the same per cent bound is also obtained in a tube containing antibody and an excess of unlabeled $\mathrm{T}_{3}$. Since there was no difference in the blank value in the presence of increasing quantities of $T_{3}$, only six blanks containing $0.2 \mathrm{ml}$ of $T_{3}$-free serum were used for each standard curve. The blank is slightly greater in unknown tubes from patients with normal TBG levels (mean for $0.2 \mathrm{ml}, 9.4 \pm 1.27 \% \mathrm{sD}$ ). In serum from pregnant patients and in cord serum with TBG levels about twice normal, the blank is $2-3 \%$ higher than that obtained with normal serum. Blanks in the serum enriched with greater than $50 \mu \mathrm{g} \mathrm{T}_{4} / 100 \mathrm{ml}$, are $2-3 \%$ lower than those in normal serum simultaneously assayed.

A displacement curve performed using increasing quantities of $\mathrm{T}_{3^{-}}{ }^{125} \mathrm{I}$ is superimposable on a standard curve using increasing quantities of unlabeled $T_{3}$ up to $0.4 \mathrm{ng}$ of $\mathrm{T}_{3}$ per assay tube. The per cent bound in the blank is unchanged with addition of as much as 40 times the amount of tracer used in these studies. We have observed that tracer $\mathrm{I}^{-}$, which may be present in small quantities (less than $2 \%$ ) in the $\mathrm{T}_{3^{-}}$ ${ }^{125} \mathrm{I}$ preparations, is not bound to the charcoal-dextran. This is therefore, eliminated by the formula given in Table I. Sufficient counts in the $1 \mathrm{ml}$ supernate are collected to provide less than $2.5 \%$ counting error.

We have chosen to express $\mathrm{T}_{3}$ concentrations as nanograms per milliliter since it provides a convenient terminology; the normal value being approximately $1 \mathrm{ng} / \mathrm{ml}$ of hu- man serum. Secondly, $1 \mathrm{ml}$ closely reflects the quantity of serum assayed.

Enrichment with $T_{4}$. Thyroxine (free acid) was subjected twice to paper chromatography in a tertiary amyl alcohol-hexane-ammonia system as previously described (5). After the second chromatography, the $T_{4}$ was eluted from the paper with a portion of pooled human serum. This serum was then diluted with $\mathrm{T}_{3}$-f ree serum to give a net increase in $\mathrm{T}_{4}$ concentration of about $50-100 \mu \mathrm{g}$ of $\mathrm{T}_{4} / 100 \mathrm{ml}$ as estimated by the Murphy-Pattee technique (21). All $\mathrm{T}_{4}$ values are corrected for $80 \%$ extraction of $\mathrm{T}_{4}$ into ethanol and are expressed as total $\mathrm{T}_{4}$.

Serum specimens. Samples of blood were generally obtained at 7 a.m. from patients at Presbyterian-University Hospital, Oakland Veterans Administration Hospital, and Montefiore Hospital, all in Pittsburgh, $\mathrm{Pa}$. Some patients were hospitalized on the Clinical Research Unit of Presbyterian-University Hospital. After clotting, the samples were centrifuged and the serum frozen at $-20^{\circ} \mathrm{C}$ until assay. When thyroid-stimulating hormone (TSH) was administered, $10 \mathrm{U}$ were given i.m. and specimens were obtained at various intervals as described.

Materials. All solutions were made using distilled, deionized water and reagents were obtained from commercial sources: "Morpho" carbodiimide (CDI) from Aldrich ChemChemical Co., St. Louis, Mo., crystalline BSA used in ical, "ethyl" CDI and L-thyroxine (free acid) from Sigma coupling from ICN Nutritional Biochemicals Div., Cleveland, Ohio, crystalline HSA and $\mathrm{Na} 3,5,3^{\prime}$ L-triiodothyronine from Mann Research Labs., Inc., New York. Statistical analyses were performed by standard methods (22).

\section{RESULTS}

Standard curve. Addition of increasing quantities of $T_{3}$ results in progressive decreases in the per cent $T_{3-{ }^{-125}} \mathrm{I}$ bound as is shown in Fig. 1 (curve A). At the antiserum concentration generally used $(1 / 106,000)$, the per cent $\mathrm{T}_{\mathrm{B}^{-}}{ }^{125} \mathrm{I}$ bound in the 0 tube is $50-60 \%$. The presence of $0.1 \mathrm{ng} \mathrm{T}_{3}$ causes displacement of $55-65 \%$ of the $\mathrm{T}_{3}{ }^{125} \mathrm{I}$ bound at $0 \mathrm{~T}_{3}$ concentration. The displacement curve in the presence of salicylate and $T_{3}$ free serum is slightly lower and has a steeper initial slope than that which is obtained in the presence of buffer alone (curve $B$ ). The effect of salicylate on the standard curve can be appreciated by comparison of curve $A$ with curve $C$, obtained by omitting salicylate from tubes containing human serum. Displacement of tracer $T_{3}$ from antibody in the latter circumstances is obscured by the binding of $\mathrm{T}_{3^{-}}{ }^{125} \mathrm{I}$ presumably to the TBG present in human serum.

When increasing quantities of hyperthyroid serum are assayed, the displacement curve is superimposable on the standard curve in $\mathrm{T}_{3}$-free serum. A representative example of such an experiment is shown in Fig. 2. In this figure, the per cent $\mathrm{T}_{3^{-}}{ }^{125} \mathrm{I}$ bound is expressed relative to the 0 value. Thus, as little as $5 \mu 1$ of this patient's serum provided significant displacement of ${ }^{125} \mathrm{I}$ from the antibody.

Cross-reactivity of the antiserum with L-thyroxine, monoiodotyrosine $(M I T)$, and diiodotyrosine (DIT). 


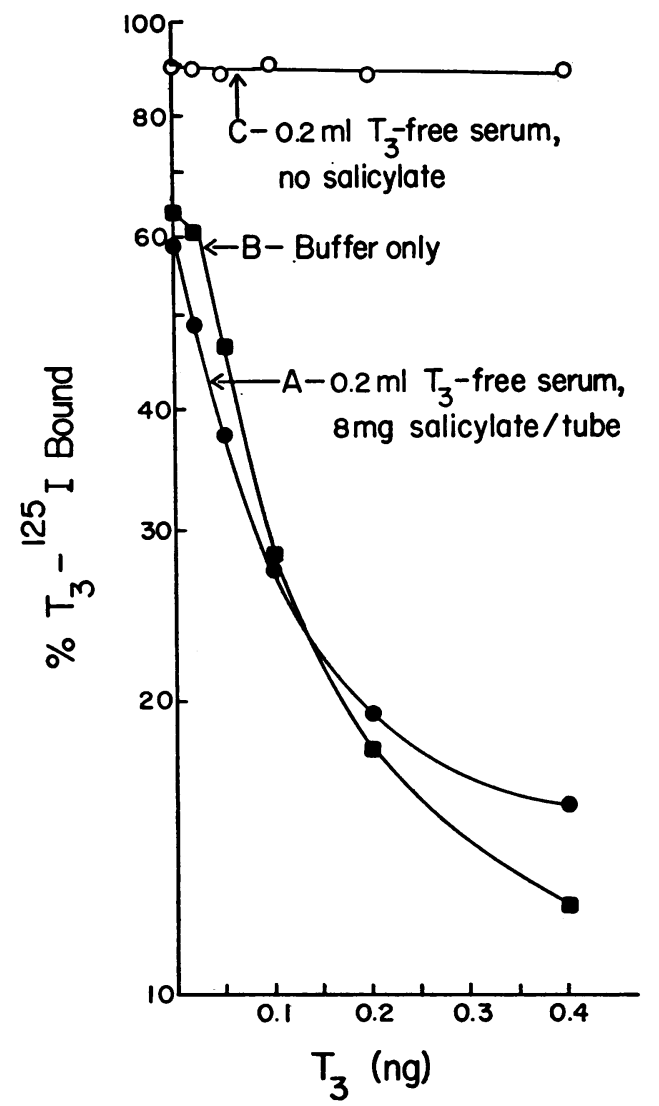

Figure 1 Comparison of standard curves performed under various conditions. The per cent $T_{3^{-}}{ }^{125} \mathrm{I}$ bound is not corrected for the per cent $T_{8^{-}}{ }^{25} \mathrm{I}$ bound in the absence of antibody (blank). The blank values were as follows: curve $\mathrm{A}, 8.2 \% ; \mathrm{B}, 3.3 \% ; \mathrm{C}, 87 \%$. The standard error of the mean of the triplicate determinations is less than $2 \%$ for all points.

\section{TABLE II}

Effect of $T_{4}$ Enrichment of Human Serum on $T_{2}$ Concentrations

\begin{tabular}{|c|c|c|c|c|c|c|c|}
\hline & $\begin{array}{c}\text { Initial } \\
T_{4}\end{array}$ & Final $T_{4}$ & $\begin{array}{l}\text { Net in- } \\
\text { crease } \\
T_{4}\end{array}$ & $\begin{array}{c}\text { Initial } \\
T_{8}\end{array}$ & Final $T_{3}$ & $\begin{array}{c}\text { Net in- } \\
\text { crease } \\
T_{8}\end{array}$ & $\begin{array}{c}\text { Net in- } \\
\text { crease } \\
T_{2} / \text { net } \\
\text { increase } \\
T_{6}\end{array}$ \\
\hline & $n g / m l$ & $n g / m l$ & $n g / m l$ & $n g / m l$ & $n g / m l$ & $n g / m l$ & \\
\hline A & $61^{*}$ & 1154 & 1093 & $0.41 \ddagger$ & 1.538 & 1.12 & 0.0010 \\
\hline \multirow[t]{2}{*}{ B } & 43 & 526 & 483 & $0.20 \ddagger$ & $0.80 \S$ & 0.60 & 0.0012 \\
\hline & & & & & & Mean & 0.0011 \\
\hline
\end{tabular}

* $T_{4}$ values are the mean of duplicate determinations.

$\ddagger$ Calculated from the dilution of pooled serum with $T_{3}$-free serum $(A=1 / 1, B=1 / 3)$.

$\delta T_{3}$ values are the mean of duplicate determinations at two dilutions.
Table II shows the results of the $T_{3}$ assay in sera enriched with $T_{4}$ as described above. It would appear that in this assay system, approximately $100 \mathrm{ng}$ of $\mathrm{T}$. are required to produce displacement of $\mathrm{T}_{3}{ }^{120} \mathrm{I}$ from the antibody equivalent to $0.1 \mathrm{ng}$ of $\mathrm{T}_{3}$ (approximately $50 \%$ displacement). The above calculation for cross-reactivity with $T_{4}$ assumes that there is no $T_{3}$ present as a contaminant in the $T_{4}$ preparation. The data were alternatively consistent with the interpretation that even after repeated chromatography, there is a $0.1 \% \mathrm{~T}_{\mathbf{3}}$ contamination of the $T_{\text {s }}$ preparation. From our previous studies, the latter seems more likely (5). If the $\mathrm{T}$. preparation were free of $T_{3}$, the $T_{4}$ present in normal concentration in human serum (approximately $80 \mathrm{ng} /$ $\mathrm{ml}$ ), would result in an artifactual overestimate of only

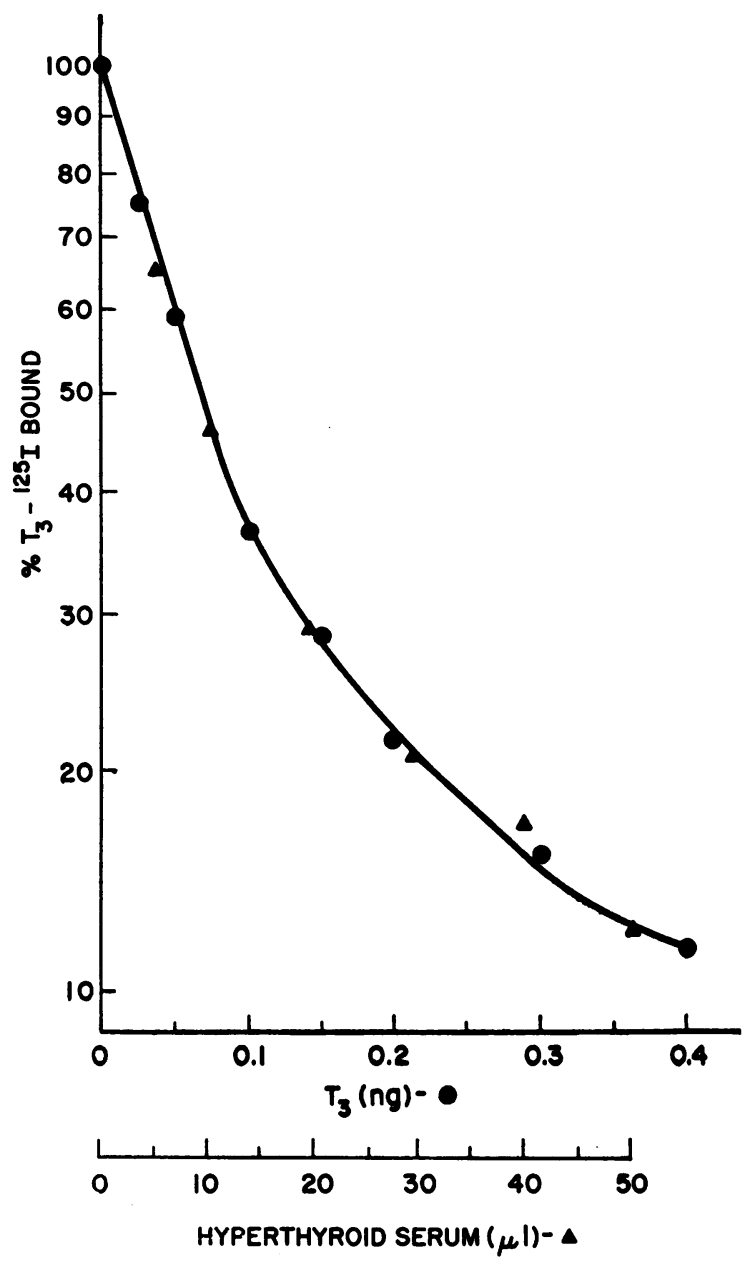

Figure 2 Comparison of displacement of $\mathrm{T}_{3^{-125}} \mathrm{I}$ by $\mathrm{T}_{8}$ and by hyperthyroid serum. Results are the mean of triplicate determinations. The standard error of the mean is less than $2 \%$ of the counts of tracer bound at $0 \mathrm{~T}_{3}$ for all points. The estimated $T_{3}$ concentration in this hyperthyroid serum was $7.4 \mathrm{ng} / \mathrm{ml}$ and the $\mathrm{T}_{\text {s }}$ concentration $23.2 \mu \mathrm{g} / 100 \mathrm{ml}$. 
TABLE III

Recovery of $T_{3}$ Added to Normal Serum

\begin{tabular}{ccccc}
\hline & & \multicolumn{2}{c}{$T_{3}$} & \\
\cline { 3 - 5 } & Portion & Expected & Recovered & $\begin{array}{c}\text { Recovered/ } \\
\text { expected }\end{array}$ \\
\hline & $\mu l$ & $n g$ & $n g$ & $\%$ \\
Pool $+4 \mathrm{ng} / \mathrm{ml} \mathrm{T}_{\mathbf{3}} *$ & 100 & 0.48 & $0.48 \ddagger$ & 100 \\
& 50 & 0.24 & 0.24 & 100 \\
& 25 & 0.12 & 0.13 & 108 \\
& 10 & 0.048 & 0.051 & 106 \\
& & & Mean & $103.5 \pm 2.1$ (SE)
\end{tabular}

* Endogenous $T_{3}$ concentration of the pool was $0.81 \mathrm{ng} / \mathrm{ml}$.

¥ Mean of duplicate determinations.

$0.08 \mathrm{ng}$ of $\mathrm{T}_{3} / \mathrm{ml}$ due to cross-reaction with $\mathrm{T}_{4}$. There is no displacement of $\mathrm{T}_{3}$ by as much as $1000 \mathrm{ng}$ of MIT or DIT.

Recovery of $T_{s}$ added to normal human serum. When normal human serum was enriched with $4 \mathrm{ng}$ of $\mathrm{T}_{3} / \mathrm{ml}$ and various portions were assayed, the mean recovery was $103 \%$ over a broad range of $\mathrm{T}_{3}$ concentrations (Table III). Recovery of $\mathrm{T}_{3}$ from a sample of human serum containing $2 \mathrm{ng} / \mathrm{ml}$ added $\mathrm{T}_{3}$ was $1.98 \pm 0.14$ (sD) $\mathrm{ng} / \mathrm{ml}$ in 10 consecutive assays.

Reproducibility of the assay. Results of $\mathrm{T}_{3}$ determinations in three different serum preparations of varying $\mathrm{T}_{3}$ content are given in Table IV. Using serum of extremely low $\mathrm{T}_{3}$ concentration (assay of 25 and $50 \mathrm{pg}$ of $T_{3}$ ) the per cent standard deviation within the assay is 9.2. However, at higher concentrations (assay of 80 and $160 \mathrm{pg}$ or 100 and $200 \mathrm{pg}$ ), the within-assay per cent standard deviation is substantially less : $2-4 \%$. The between-assay variation is slightly greater, though with more experience with the assay this has been decreased to about $5 \%$.

Further evidence of the precision of this assay is given in Table V. This table presents the results of five consecutive immunoassays. The data demonstrate that the quantities of $T_{8}$ recovered in different portions of various unknown samples is directly proportional to the volume of the unknown serum assayed. Thus, the calculated $T_{8}$ concentration is constant regardless of the quantities of serum assayed within the limit of the standard curve. This is true when both small (less than $100 \mathrm{pg}$ ) and large (greater than $100 \mathrm{pg}$ ) quantities of $T_{3}$ are measured in the greater portion. This provides assurance that the $\mathrm{T}_{3}$-free serum used as diluent to achieve a constant serum volume of $0.2 \mathrm{ml}$ does not either artifactually lower or increase the estimated $T_{3}$ concentration. In practice, we have attempted to assay sufficient quantities of serum to measure between 50 and $250 \mathrm{pg}$ in the portions sampled. This allows at least two points on the standard curve above and below the unknown value.
TABLE IV

Reproducibility of the $T_{3}$ Immunoassay

\begin{tabular}{lccc}
\hline Sample & \multicolumn{1}{c}{$\mathrm{T}_{3}$} & $\% \mathrm{SD}$ & $\mathrm{N}$ \\
\hline Within assay & $n g / m l$ & & \\
A & $0.25 \pm 0.023^{*}$ & 9.2 & $9 \ddagger$ \\
B & $0.81 \pm 0.029$ & 3.6 & 10 \\
C & $1.03 \pm 0.03$ & 2.2 & 10 \\
\multicolumn{2}{l}{ Between assays } & & \\
D & $0.75 \pm 0.06$ & 8.0 & 10 \\
\hline
\end{tabular}

* Mean \pm SD of duplicate determinations.

$\ddagger N$ refers to the number of pairs.

Results of $T$ s assays in euthyroid subjects, patients with hyper- and hypothyroidism, pregnant patients at delivery, and cord sera. The mean $\mathrm{T}_{3}$ level in 38 clinically euthyroid subjects was $1.10 \mathrm{ng} / \mathrm{ml} \pm 0.25$ (SD). This is indicated in Fig. 3 as a shaded area which is 1 SD above and below the mean. Hyperthyroid subjects have values which range from a low of $1.88 \mathrm{ng} / \mathrm{ml}$ in a subject with hyperthyroidism and TBG deficiency to a high of $23.8 \mathrm{ng} / \mathrm{ml}$ in a subject with a $\mathrm{T}$, level of $50 \mu \mathrm{g} / 100 \mathrm{ml}$. This patient had been treated for a period of months with small doses of iodide which had obviously not controlled her hyperthyroidism. The values in hypothyroid patients were obtained before institution of treatment. The mean $T_{3}$ level in 25 hypothyroid patients was $0.39 \pm 0.21 \mathrm{ng} / \mathrm{ml}$. Thus, there would appear to be greater overlap between this group and the normals than was observed with the hyperthyroid patients. All of these patients were spontaneously hypothyroid or had become hypothyroid after surgery.

\section{TABLE V}

Results of Determinations in Paired Portions of Different Volumes in Five Consecutive Assays

\begin{tabular}{|c|c|c|c|c|c|}
\hline \multicolumn{6}{|c|}{ Quantity of $T_{3}$ in larger portion } \\
\hline \multicolumn{3}{|c|}{$<0.100 \mathrm{ng}$} & \multicolumn{3}{|c|}{$>0.100 \mathrm{ng}$} \\
\hline Volumes* & Pairs & $T_{3}$ recovered & Volumes & Pairs & $T$, recovered \\
\hline$\mu l$ & & $n g$ & $\mu l$ & & $\boldsymbol{n g}$ \\
\hline 200 & 24 & $0.0677 \pm 0.0047 \ddagger$ & 200 & 45 & $0.219 \pm 0.012$ \\
\hline 100 & & $0.0332 \pm 0.0025$ & 100 & & $0.108 \pm 0.005$ \\
\hline 100 & 3 & $0.077 \pm 0.0061$ & 100 & 17 & $0.220 \pm 0.021$ \\
\hline 50 & & $0.039 \pm 0.0036$ & 50 & & $0.109 \pm 0.011$ \\
\hline 50 & 8 & $0.0578 \pm 0.0120$ & & & \\
\hline 25 & & $0.0332 \pm 0.0075$ & & & \\
\hline
\end{tabular}

* The volumes refer to the quantity of the portions of unknown serum which was assayed in duplicate. Each unknown was measured in only one pair. $\ddagger$ Mean \pm SE. 


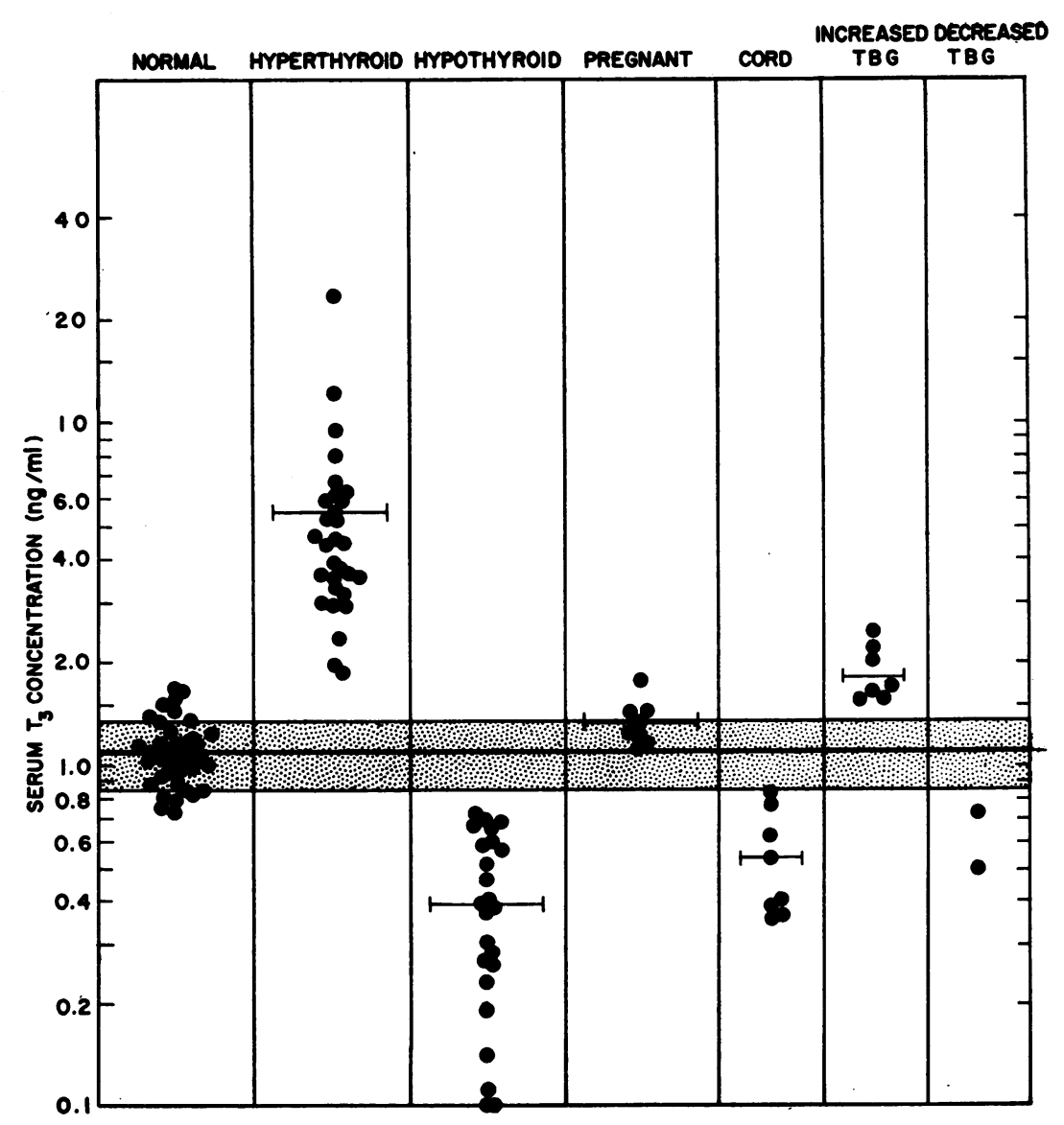

FIGURE 3 Results of $T_{3}$ determinations in various groups of patients. The heavy line and the stippled area represent the mean \pm 1 sD in 38 euthyroid subjects. The bars indicate the mean in various groups. $T_{3}$ levels are plotted on a log scale to allow convenient presentation of both high and low levels.

In eight pregnant patients at the time of delivery, the $T_{s}$ level was in the upper normal range (mean 1.33 $\mathrm{ng} / \mathrm{ml}$ ). Of great interest are the $T_{8}$ values in cord sera obtained simultaneously with the maternal sample in these patients. The mean $\mathrm{T}_{3}$ level $(0.53 \mathrm{ng} / \mathrm{ml})$ is about 2 sD below the mean normal value. The paired cord-maternal $T_{3}$ levels are significantly different by paired $t$ test $(P<0.001)$. The implications of this observation are discussed further below.

Serum $T_{3}$ concentrations were examined in seven euthyroid patients with increased TBG levels (mean $45 \mu \mathrm{g} \mathrm{T}_{4} / 100 \mathrm{ml}$, range $31-65 \mu \mathrm{g} \mathrm{T}_{4} / 100 \mathrm{ml}$ ). The mean serum $\mathrm{T}_{3}$ concentration in these patients was 1.78 \pm 0.25 ( $\mathrm{SD}) \mathrm{ng} / \mathrm{ml}$ or about $3 \mathrm{SD}$ above the normal mean. Two euthyroid patients with TBG deficiency ( 7.9 and $10.7 \mu \mathrm{g} \mathrm{T}_{4} / 100 \mathrm{ml}$ ) have been identified and both have $\mathrm{T}_{3}$ levels in the low normal range.

Correlation of $T_{s}$ and $T_{4}$ concentrations. In Fig. 4, a plot is constructed of the $T_{3}$ and $T_{4}$ levels determined on the same specimens. In general, there is the expected good correlation between $T_{3}$ and $T_{4}$ levels in normals and hyperthyroid subjects. It would appear, however, in the hypothyroid subjects, that there is more overlap with the normals in $T_{3}$ levels than in $T_{4}$ levels. The data from the cord blood obtained at the time of delivery are the only group of results that appear to deviate from the general pattern. Here, there appears to be a distinct decrease in the serum $T_{3}$ relative to $T_{4}$ levels. Both the cord sera and the maternal samples had increased TBG binding capacities (35-50 $\mu \mathrm{g} \quad \mathrm{T}_{4} / 100$ $\mathrm{ml})$.

Response of $T_{s}$ to physiologic influences. In Fig. 5, the utility of this assay in observing rapid physiologic changes in thyroidal $T_{s}$ secretion is illustrated. The data from the TSH injections in euthyroid subjects is representative of that we have seen in a series of seven such studies in which $T_{3}$ and $T_{4}$ concentrations after TSH were compared (Table VI). There is a substan- 


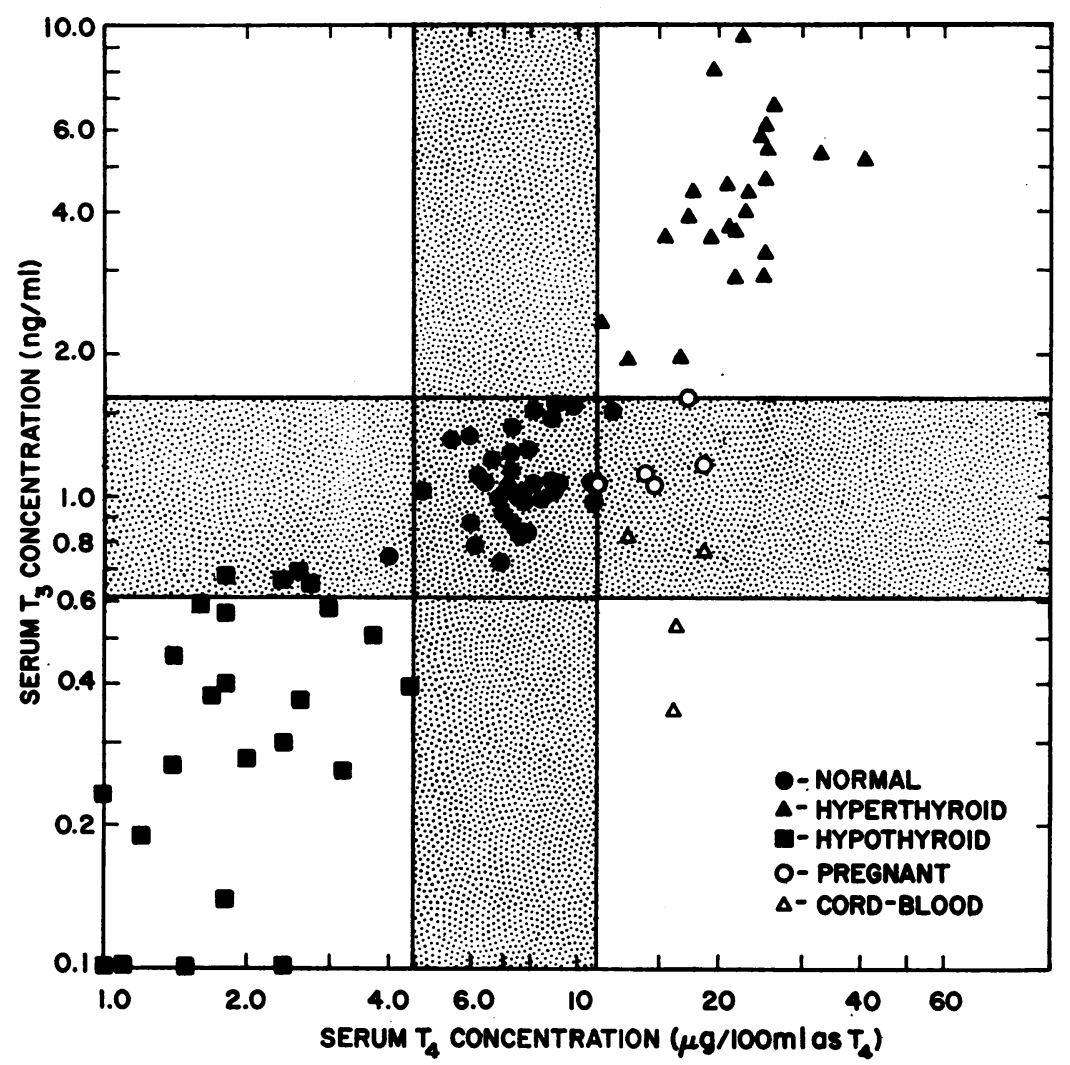

FIGURE $4 \quad T_{3}$ and $T_{4}$ concentrations measured in the same serum samples from normals, from patients with various thyroid diseases, from pregnant patients at the time of delivery and in cord sera. The stippled area represents the mean \pm 2 SD for both $T_{3}$ and $T_{4}$ levels based on the data obtained in these normal subjects. No attempt was made to quantitate precisely levels of $T_{3}$ less than $0.1 \mathrm{ng} / \mathrm{ml}$ or less than $1.0 \mu \mathrm{g}$ of $\mathrm{T}_{4} / 100 \mathrm{ml}$. The $\log$ scale is used to allow presentation of a broad range of values.

tial increase in $\mathrm{T}_{3}$ concentrations after $\mathrm{TSH}$ which reaches a mean level of $205 \%$ of the baseline value by $8 \mathrm{hr}$. The T. levels have increased only $41 \%$ at this time and even by $24 \mathrm{hr}$ have not increased to the degree that the $T_{3}$ levels do. It is not as yet clear from these studies when the peak $T_{8}$ levels are reached but it appears to be somewhere between 8 and $24 \mathrm{hr}$ after TSH injection. In both euthyroid patients shown in Fig. 5, as well as in the others we have studied, further injections of TSH result in additional increases in $T_{3}$ and $T_{4}$ levels.

The rapid decrease in $T_{s}$ levels after either removal of the pituitary or thyroid gland is depicted in the same figure. There is a prompt decrease the day of surgery, but little if any decrease is observed over the next few days. As might be expected, $T_{s}$ levels fall significantly faster than do $T_{4}$ levels under these circumstances. The half-life for $T_{3}$ has been estimated to be approximately 1 day while that for $T_{4}$ in the euthyroid patient can be expected to be about 7 days (23). This would appear to account for the rapid decrease of $T_{s}$ in the initial $24 \mathrm{hr}$ after subtotal thyroidectomy or hypophysectomy. The reasons for the failure of serum $T_{s}$ to reach undetectable levels are discussed further below. Both patients subsequently became clinically hypothyroid with decreases of $T_{4}$ and $T_{3}$ into the hypothyroid range.

\section{DISCUSSION}

Methodology. The direct immunoassay of $\mathrm{T}_{\mathrm{s}}$ in human serum has been technically difficult due to: (a) small quantities of $T_{3}$ present in the serum, $(b)$ the presence in serum of relatively large amounts of a similar hormone, $T_{4}$; and $(c)$ the presence of $T B G$, a protein which has a relatively high affinity for the hormone to be measured. The method described above appears to provide a satisfactory solution to these problems. The sensitivity of the assay as described is sufficient to measure 25 pg of $T_{3}$ and with further dilution of the antiserum as little as $12.5 \mathrm{pg}$ of $\mathrm{T}_{3}$. The latter allows quantitation of 


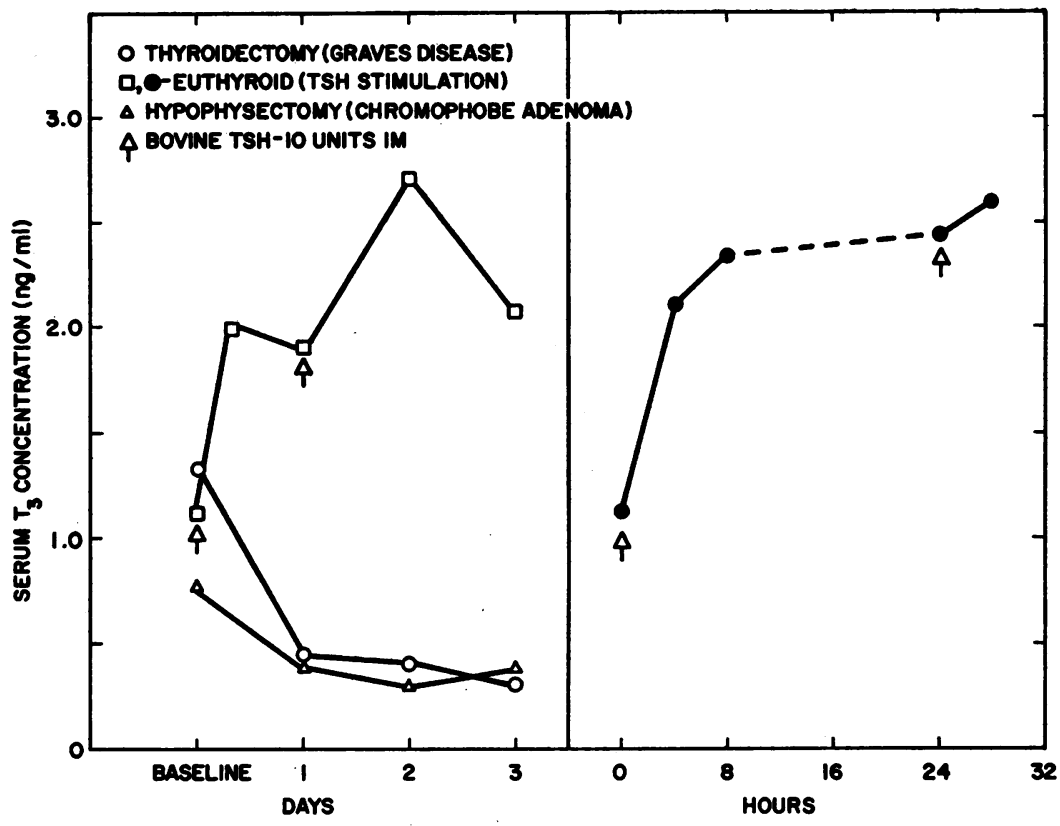

FIGURE 5 Response of $T_{3}$ to alterations in thyroid hormone secretion. The results of $T_{3}$ levels in four patients are presented. Two of these were given $10 \mathrm{U}$ of $\mathrm{TSH}$ at the times indicated by the arrows. Thyroid secretion was inhibited in two patients, one by thyroidectomy and the other by hypophysectomy.

$\mathrm{T}_{3}$ in whole serum containing as little as $0.06 \mathrm{ng} / \mathrm{ml}$, levels rarely reached even in profound hypothyroidism.

It is not clear from our studies whether the high titer of antisera obtained in these rabbits is due to more than chance. The initial production of antibody to $T_{2}$ was reported by Brown, Ekins, Ellis, and Reith (9). However, these authors as well as the other laboratories in which various $T_{3}$-protein conjugates have been utilized, have not reported antiserum with usable dilutions higher than $1-4,000(9-13)$. It is possible that the partial insolubility of the $\mathrm{T}_{3}-\mathrm{BSA}$ conjugate is related to its increased efficacy, but this is pure speculation. It would appear from preliminary data, that antisera obtained from the three other animals immunized with the

TABLE VI

Effect of Exogenous TSH on Serum $T_{3}$ and $T_{4}$ Concentrations in Euthyroid Subjects

\begin{tabular}{|c|c|c|c|c|c|c|}
\hline \multirow[b]{3}{*}{ Subject } & \multicolumn{3}{|c|}{ Serum $T_{3}$ concentration } & \multicolumn{3}{|c|}{ Serum $T_{4}$ concentration } \\
\hline & \multirow[b]{2}{*}{ Basal } & \multicolumn{2}{|c|}{ After $10 \mathrm{U}$ TSH* } & \multirow[b]{2}{*}{ Basal } & \multicolumn{2}{|c|}{ After $10 \mathrm{U} \mathrm{TSH}^{*}$} \\
\hline & & $8 \mathrm{hr}$ & $24 \mathrm{hr}$ & & $8 \mathrm{hr}$ & $24 \mathrm{hr}$ \\
\hline & \multicolumn{3}{|c|}{$n g / m l$} & \multicolumn{3}{|c|}{$\mu \mathrm{g} / 100 \mathrm{ml}$} \\
\hline D. F. & 1.14 & 2.00 & 1.93 & 8.8 & 11.9 & 13.1 \\
\hline D. L. & 1.63 & 3.50 & 3.00 & 9.4 & 10.6 & 15.9 \\
\hline H. W. & 1.14 & 2.35 & 2.44 & 6.4 & 9.8 & 11.2 \\
\hline E. $\mathrm{O}$. & 0.73 & 1.14 & 1.35 & 6.9 & 11.6 & 10.2 \\
\hline E. A. & 0.93 & 1.75 & 1.58 & 7.6 & 8.0 & 11.5 \\
\hline S. B. & 0.56 & 1.82 & 1.24 & 4.7 & 8.3 & 8.6 \\
\hline C. S. & 1.00 & 2.07 & 2.94 & 7.4 & 11.7 & 17.8 \\
\hline Mean \pm SEM & $1.02 \pm 0.13$ & $2.09 \pm 0.27$ & $2.07 \pm 0.28$ & $7.3 \pm 0.6$ & $10.3 \pm 0.6$ & $12.6 \pm 1.2$ \\
\hline Per cent increase & & 105 & 103 & & 41 & 72 \\
\hline
\end{tabular}

* Bovine TSH given intramuscularly. 
initial BSA-T $\mathrm{T}_{3}$ conjugate are of equally potent affinity, although two of the animals died before high titers were attained. This suggests that the high titer is probably not an unusual response of a single animal. In addition to the high titer and high affinity, the antiserum shows very low, if any cross-reactivity with $\mathrm{T}_{4}, \mathrm{MIT}$, or DIT.

The use of salicylate is a critical factor in the success of this assay as is demonstrated in Fig. 1. Its effect would appear to confirm previous evidence that salicylate inhibits the binding of $T_{3}$ to TBG $(15,16)$. We have shown that salicylate concentrations of approximately 10 -fold greater magnitude are required to cause displacement of $T_{4}$ equivalent to that of $T_{3}$ in dilute human serum. Therefore salicylate has the theoretical advantage of displacing more $T_{3}$ from $T B G$ than $T_{4}$ and would tend to decrease the potential for cross-reactivity of $T_{4}$ with $T_{3}$ in the assay.

This property would presumably also be shared by the compounds used by other investigators to inhibit $\mathrm{T}_{3}-\mathrm{TBG}$ binding. Tetrachlorthyronine has been reported to be effective by Mitsuma, Gershengorn, Colucci, and Hollander and diphenylhydantoin by Lieblich and Utiger $(12,13)$. A preliminary study reported by Gharib et al. does not appear to consider the influence of the TBG in the serum on the $T_{3}$ assay (10). This may account for the higher normal values reported by these authors since addition of TBG could simulate addition of $T_{3}$ by competing with the antibody for tracer $\mathrm{T}_{3}$.

Since the presence of serum (probably primarily due to its TBG content) alters the standard curve, it is necessary to include a constant amount of serum in the unknown and standards during the assay. Furthermore, since changes in serum TBG content (idiopathic or pregnancy related) cause parallel changes in the per cent $\mathrm{T}_{3-}{ }^{125} \mathrm{I}$ bound in the absence of antibody as described above, it is necessary to monitor the blank value for each unknown serum. With these data, the observed per cent bound can be corrected for that per cent of $\mathrm{T}_{3}{ }^{225} \mathrm{I}$ that would be bound in the absence of antibody. However, as may be readily appreciated, this is a somewhat tedious procedure in that eight tubes are required for duplicate immunoassay of $T_{3}$ in two dilutions. We are currently accumulating a larger body of data over a period of intensive use of this assay to determine whether or not individual blanks are necessary when $T_{4}$ and $T B G$ levels are approximately normal. The significance of the small changes in the blank value is dependent on the quantity of $T_{3}$ in the portion which has been assayed. If this is small and the results are high on the curve the $2-3 \%$ change is almost negligible. On the other hand, if the per cent bound is low, then the difference of $3 \%$ represents a larger fraction of the observed per cent bound and may change the $T_{3}$ value considerably. The demonstrated precision of the assay as described ap- pears to justify the use of the simultaneous blanks in that differences of greater than $6 \%$ in normal or hyperthyroid $T_{3}$ values are statistically significant when the samples are measured in the same assay. The dextrancoated charcoal may offer some advantages over doubleantibody systems in that the effect of TBG alterations alone on the distribution of $\mathrm{T}_{3}{ }^{125} \mathrm{I}$ in the serum sample can be recognized and a correction applied.

The use of charcoal to obtain a $\mathrm{T}_{3}$-free serum has not previously been described. The best justification for the use of this preparation is presented in Table V. This shows that virtually identical concentrations of $T_{3}$ are calculated from the measurements at two different dilutions of the same sera using a variety of volumes at both high and low $\mathrm{T}_{3}$ levels. If this $\mathrm{T}_{3}$-free serum did not behave identically with normal serum one would anticipate a systematic difference in the two values.

Observed $T_{\mathbf{s}}$ values in various clinical states. In general, the $T_{3}$ values observed in normals, hyper- and hypothyroid subjects are comparable to those reported by other authors using a radioimmunoassay for $\mathrm{T}_{3}$. The normal value of 1.1 is somewhat lower than that reported by Mitsuma et al. ( $1.4 \mathrm{ng} / \mathrm{ml})$ as is the mean value in hypothyroid serum $(0.39 \mathrm{ng} / \mathrm{ml}$ as opposed to $0.60 \mathrm{ng} /$ $\mathrm{ml}$ [12]). The values are likewise lower than those of Lieblich and Utiger (normal $1.5 \mathrm{ng} / \mathrm{ml}$ and hypothyroid $0.99 \mu \mathrm{g} / \mathrm{ml}$ [13]). Our results are higher than those reported by Chopra, Solomon, and Beall ( $80 \%$ of normals less than $1 \mathrm{ng} / \mathrm{ml}$ ) but the assay described by these authors was not sufficiently sensitive to measure $T_{3}$ concentrations less than $1 \mathrm{ng} / \mathrm{ml}$ (11). The values in hyperthyroid serum are similar to those previously reported (10-13). The $T_{3}$ concentrations are significantly lower than the levels we have previously obtained using a modification of the Sterling assay (5). In sera which we have assayed by both methods, we find the results using immunoassay to be $60-70 \%$ of those initially reported. We believe the present values to be more accurate and attribute the differences between the two to artifactual elevation of $T_{3}$ values due to $T_{4}$ to $T_{3}$ conversion and some contamination of the $T_{3}$ spot with $T_{4}$ when the Sterling method is used (5). The data in Figs. 3 and 4 suggest that there is some overlap between $T_{s}$ levels in normals and the various thyroid states, but probably no more than has been observed for $T_{4}$ levels.

The serum $T_{3}$ values obtained in pregnant patients would appear to be similar to the results observed for $T$. levels in such patients, i.e. they are in the upper portion of the normal range presumably reflecting the presence of increased TBG levels. The group in which the $T_{3}$ results deviate strikingly from the expected values is that of the cord sera. In these eight subjects the $T_{3}$ values are distinctly lower than would be expected based on $T$. values and some are clearly in the hypothyroid range. 
We have obtained similar low values in both umbilical artery and vein sera suggesting that this value is truly representative of the neonatal $T_{3}$ levels. Therefore, one may speculate that this low $T_{3}$ value is causally related to the increase in TSH secretion which has been observed by several investigators in the early hours of neonatal life.

Aside from the diagnosis of various thyroid states, the immunoassay for $T_{3}$ appears to be a useful tool in other studies of thyroid function. The effects of TSH on $\mathrm{T}_{3}$ levels are quite marked at short time intervals after administration of TSH. Thus, in the euthyroid patients studied, a mean increase of $105 \%$ in $\mathrm{T}_{\mathbf{3}}$ levels has been observed within $8 \mathrm{hr}$ after TSH administration. Triiodothyronine levels would then appear to be a more sensitive index of TSH response than the T/ levels which are increased only $41 \%$ at this time.

In addition, it would appear from limited experience that the $T_{3}$ level may have some predictive value in the assessment of the future thyroid function of patients subjected to pituitary or thyroid surgery. Because of the short half-life of $T_{3}$, elimination of thyroidal $T_{3}$ secretion is associated with a rapid decrease of the previously normal $T_{3}$ into the hypothyroid range. The residual $T_{3}$ in the serum of these two patients is presumably in large part derived from $T_{4}$ to $T_{3}$ conversion. While more experience is needed to determine whether or not patients with a decrease of $T_{3}$ into the hypothyroid range immediately postoperatively will invariably remain hypothyroid, there are obvious diagnostic advantages to a test sensitive to rapid changes in thyroid function.

One of the most intriguing aspects of the immunoassay of $T_{3}$ is the ability of the rabbit to generate a specific antibody against a compound which differs by only one atom (albeit a large one) from another hormone. It has been our experience that while the specificity of the antisera are not nearly so great, excellent titers of anti- $\mathrm{T}_{3}$ antisera are also stimulated by thyroglobulin, though this experience is not universal (24). One may speculate that perhaps $T_{3}$ is the better antigen because $T_{4}$, even in thyroglobulin, is deiodinated after injection into the animal leaving only, or primarily, $T_{s}$ as the antigen.

\section{ACKNOWLEDGMENTS}

The author would like to express his appreciation to Miss Jitka Dockalova, Mrs. Darina Sipula, and Miss Regina Oswalt for their careful technical assistance.

These studies were supported by National Institute of Health Grant No. AM-14283 from the National Institute of Arthritis and Metabolic Diseases, the Health Research and Services Foundation of Pittsburg, Pa., Grant No. M-10, the Dreyfus Charitable Fund, and the General Clinical Research Center Grant No. FR-56 from the National Institutes of Health.

\section{REFERENCES}

1. Gross, J. and R. Pitt-Rivers. 1952. The identification of 3:5: $3^{\prime}$ triiodothyronine in human plasma. Lancet. 1: 439.

2. Nauman, J. A., A. Nauman, and S. C. Werner. 1967. Total and free triiodothyronine in human serum. J. Clin. Invest. 46: 1346.

3. Sterling, K., D. Bellabarba, E. S. Newman, and M. A. Brenner. 1969. Determination of triiodothyronine concentration in human serum. J. Clin. Invest. 48: 1150.

4. Braverman, L. E., S. H. Ingbar, and K. Sterling. 1970. Conversion of thyroxine ( $\left.T_{4}\right)$ to triiodothyronine $\left(T_{3}\right)$ in athyreotic human subjects. J. Clin. Invest. 49: 855.

5. Larsen, P. R. 1971. Technical aspects of the estimation of triiodothyronine in human serum: evidence of conversion of thyroxine to triiodothyronine during the assay. Metab. (Clin. Exp.). 20: 609.

6. Fisher, D. A., and J. H. Dussault. 1971. Contribution of methodological artifacts to the measurement of $T_{3}$ concentration in serum. J. Clin. Endocrinol. 32: 675 .

7. Mitsuma, T., N. Nihei, M. C. Gershengorn, and C. S. Hollander. 1971. Serum triiodothyronine: measurements in human serum by radioimmunoassay with corroboration by gas-liquid chromatography. J. Clin. Invest. 50: 2679.

8. Robbins, J., and J. E. Rall. 1967. The iodine-containing hormones. In Hormones in blood. C. H. Gray and A. L. Bacharach, editors. Academic Press Inc. Ltd., London. 2nd edition. 1: 383.

9. Brown, B. C., R. P. Ekins, S. M. Ellis, and W. S. Reith. 1970. Specific antibodies to triiodothyronine hormone. Nature (Lond.). 226: 359.

10. Gharib, H., W. E. Mayberry, and R. J. Ryan. 1970. Radioimmunoassay for triiodothyronine: a preliminary report. J. Clin. Endocrinol. 31: 709.

11. Chopra, I. J., D. H. Solomon, and G. N. Beall. 1971. Radioimmunoassay for measurement of triiodothyronine in human serum. J. Clin. Invest. 50: 2033.

12. Mitsuma, T., N. Gershengorn, J. Colucci, and C. S. Hollander. 1971. Radioimmunoassay of triiodothyronine in unextracted human serum. J. Clin. Endocrinol. 33: 364.

13. Lieblich, J. M., and R. D. Utiger. 1971. Triiodothyronine radioimmunoassay. J. Clin. Invest. 50: 60a.

14. Larsen, P. R. 1971. Salicylate-induced increases in freetriiodothyronine $\left(\mathrm{FT}_{3}\right)$ in human serum: evidence for binding of $T_{3}$ to thyroxine binding prealbumin (TBPA). Abstracts of the 53rd Meeting of the Endocrine Society. Abstr. 131.

15. Larsen, P. R. 1971. Inhibition of triiodothyronine $\left(T_{3}\right)$ binding to thyroxine-binding globulin by sodium salicylate: its application to the immunoassay of $T_{3}$ in human serum. Metab. (Clin. Exp.) 20: 976.

16. Larsen, P. R. 1972. Salicylate-induced increases in freetriiodothyronine in human serum: evidence of inhibition of triiodothyronine binding to thyroxine-binding globulin and thyroxine-binding prealbumin. J. Clin. Invest. 51: 1125.

17. Goodfriend, T. L., L. Levine, and G. D. Fasman. 1964. Antibodies to bradykinin and angiotensin: a use of carbodiimides in immunology. Science (Wash. D. C.). 144: 1344.

18. Oliver, G. C., Jr., B. M. Parker, D. L. Brasfield, and C. W. Parker. 1968. The measurement of digitoxin in 
human serum by radioimmunoassay. J. Clin. Invest. 47: 1035.

19. Elzinga, K. E., E. A. Carr, Jr., and W. H. Beierwaltes. 1961. Adaptation of the standard Durrum-type cell for reverse flow electrophoresis. Amer. J. Clin. Pathol. 36: 125.

20. Gemmill, C. L. 1955. The apparent ionization constants of the phenolic hydroxyl groups of thyroxine and related compounds. Arch. Biochem. Biophys. 54: 359.

21. Murphy, B. P. 1965. The determination of thyroxine by competitive protein-binding analysis employing an anion- exchange resin and radiothyroxine. J. Lab. Clin. Med. 66: 161.

22. Snedecor, G. W., and W. C. Cochran. 1967. Statistical Methods. Iowa State University Press, Ames. 6th edition.

23. Nicoloff, J. T., and J. Low. 1970. Triiodothyronine and thyroxine kinetics in man. Abstracts of the 52nd Meeting of the Endocrine Society. Abstr. 113.

24. Chropa, I. J., J. C. Nelson, D. A. Solomon, and G. N. Beall. 1971. Production of antibodies specifically binding triiodothyronine and thyroxine. J. Clin. Endocrinol. 32: 299. 